\title{
Screening of Soil Fungi for Cellulase Production using Carboxymethyl Cellulose Media
}

\author{
Abdulrahman Ahmad ${ }^{1}$, Mahmud Yerima lliyasu ${ }^{1}$, Ahmad Jibrin Na'Allah ${ }^{1}$, \\ Bashir Ismail Olawale ${ }^{1}$, Abubakar Madika ${ }^{1}$, Ahmed Faruk Umar ${ }^{1}$
}

\author{
${ }^{1}$ Abubakar Tafawa Balewa University \\ Tafawa Balewa Way, P. M. B. 0248, Bauchi, 740272, Nigeria
}

DOI: $10.22178 /$ pos.77-2

LCC Subject Category: QH1-278.5

Received 20.11.2021

Accepted 28.12.2021

Published online 31.12.2021

Corresponding Author:

Abdulrahman Ahmad

abdulbakory@gmail.com

(C) 2021 The Authors. This article is

licensed under a Creative Commons

Attribution 4.0 License @ (1)

\begin{abstract}
The research was conducted to isolate soil fungi and screen them for cellulase production using the zone of hydrolysis technique. Several fungi were isolated and characterised from soil environments of different locations using conventional microbiological methods. A total of six isolates were confirmed to be Penicillium chrysogenum, Emericella rogulosus, Aspergillus terreus, Aspergillus flavus, Aspergillus niger, Aspergillus fumigatus, all coded as $B G 1, B G 2, B G 3, B G 4, B G 5$ and $B G 6$, respectively. Fungal isolate BG5 has the highest percentage of occurrence (34.30\%), followed by SBG3 $(22.86 \%)$. The isolates were screened for cellulase production using the carboxymethyl cellulose (CMC) agar plate method. All the fungal isolates demonstrated cellulase production ability, with fungal isolates BG5 $(18 \mathrm{~mm})$ and BG3 (15 $\mathrm{mm}$ ) having the highest diameter of zone of cellulose hydrolysis. The research reveals the potentiality of using locally isolated soil fungi for cellulase production.
\end{abstract}

Keywords: cellulase; soil fungi; carboxymethyl cellulose; aspergillus; penicillium.

\section{INTRODUCTION}

Cellulases hydrolyse $\beta$-(1-4) glycosidic bonds in cellulose. They are produced both by bacteria and fungi. However, the enzymes produced by the aerobic fungus Trichoderma reesei are broadly studied for enzymatic hydrolysis of cellulose. These enzymes constitute non-complexed cellulase systems, i. e. systems based on synergistic discrete action of individual components rather than a stable complex [1]. The general structure of most of the cellulases can be broken down into two structural parts: the catalytic domain (CD) and the carbohydrate-binding domain (CBD), both of which are connected via a flexible linker peptide. CBD promotes the cellulase's adsorption to the cellulosic substrate's crystalline region and facilitates hydrolysis by bringing its catalytic domain near cellulose chains [1]. The degree of polymerisation, crystallinity, $\mathrm{pH}$, and temperature $[1,2]$.
Cellulases can be broadly divided into three classes based on their catalytic action as endoglucanases (EC 3.2.1.4), cellobiohydrolase (EC 3.2.1.91), and $\beta$-glucosidase (EC 3.2.1.21). Endoglucanases randomly attack the amorphous regions inside the cellulose chains on the surface of microfibrils and produce oligosaccharides of varying lengths and create new chain ends for exoglucanases. Exoglucanases hydrolyse the cellulose chain from ends making cellobioses or two units of glucose. The hydrolysis of exoglucanases is restricted to the lots of cellulose chains as their access to the substrate is hindered by their structure. $\beta$-glucosidase hydrolyses cellobiose units to form glucose units. The activity of cellulase systems is greater than the collective sum of individual actions, a phenomenon known as synergism. Synergism is a function of multiple forms of cellulases and cellulose, i. e. amorphous or crystalline. 
Cellulase production is a significant area of research globally, with the rejuvenated interest created due to their applications in lignocellulose conversion. Several investigators worldwide are working on some aspect of cellulase [3]. Production of low titers of cellulase has always been a primary concern. Thus, several workers are trying to improve the production titers by adopting multi-faceted approaches, including using better bioprocess technologies, using cheaper or crude raw materials as substrates for enzyme production, bioengineering the microorganisms, etc. [1, 3]. A significant portion of research addresses bioprocess improvement strategies for enhancing cellulases' yield and specific activities. Their review, [3] has discussed the bioprocess technologies employed for cellulase production using diverse microorganisms and the future challenges in their study.

The majority of the reports on microbial production of cellulases utilise the submerged fermentation technology (SmF). The widely studied organism used in cellulase production, Trichodérma reesei has also been tested primarily on liquid media. However, in nature, the growth and cellulose utilisation of aerobic microorganisms elaborating cellulases resemble solid-state fermentation than a liquid culture [2, 4]. During the last two decades, solid-state fermentation has regained interest due to the high titers of enzyme production employing fungal cultures [5]. The lignocellulosic substrate type had the most significant impact on cellulase secretion. Some of the substrates significantly stimulated lignocellulolytic enzyme synthesis without supplementation of the culture medium with specific inducers [6].

Nevertheless, the advantages of better monitoring and handling are still associated with the submerged cultures [7]. A direct comparison of the cellulase yields and activities in these reports is impossible due to the differences in the assay methods and how the activities are being expressed even though there is an IUPAC approved method of assay for cellulase activity determination [8]. Moreover, there is no way to compare cellulases produced by SSF and SmF.

Cellulose is the most abundant biopolymer available in nature since it is one of the major components of most plants' cell walls [9]. It is a homopolymer of anhydroglucose, with the glucose residues linked in a $ß-1,4$ fashion [10]. Cell walls of plant cells attribute their mechanical strength to cellulose. Cellulose owes its cellulose structural properties because it can retain a semicrystalline state of aggregation even in an aqueous environment, which is unusual for a polysaccharide [11].

As far as cellulose-based products are concerned, paperboard and paper are the most commonly used [12]. Smaller amounts of cellulose, when processed under appropriate conditions, can be converted to a wide variety of derivatives. These can manufacture a few commercial products like cellophane and rayon. Since cellulose is a homopolymer of a glucose derivative. It is an excellent source of fermentable sugar. It is cultivated in energy crops to produce ethanol, ethers, acetic acid, etc. Besides energy requirements, the industrial demands of cellulose are fulfilled by wood pulp and cotton crops [13].

Soil fungi are microscopic plant-like cells that grow in long threadlike structures or hyphae that make mycelium mass. The mycelium absorbs nutrients from the colonised roots, surface organic matter or the soil. It produces special hyphae that create reproductive spores. Some fungi are single-celled (e. g., yeast). Fungi have many different structures, but they can act in similar ways and thus are not as plant-specific in their needs as some soil bacteria such as Rhizobia [14].

Fungi are very successful soil inhabitants due to their high plasticity and capacity to adopt various forms in response to adverse or unfavourable conditions [15]. Due to their ability to produce a wide variety of extracellular enzymes, they can break down all kinds of organic matter, decomposing soil components and thereby regulating the balance of carbon and nutrients [16]. Fungi convert dead organic matter into biomass, carbon dioxide, and organic acids. Many species of fungi possess the ability to act as an effective biosorbent of toxic metals such as cadmium, copper, mercury, lead, and zinc by accumulating them in their fruiting bodies. However, these elements may inhibit their growth and affect reproduction [17]. The diversity and activity of fungi are regulated by various biotic (plants and other organisms) and abiotic (soil pH, moisture, salinity, structure, and temperature) factors [18, 19]. Fungi can be found in almost every environment and live in a wide range of $\mathrm{pH}$ and temperature [20].

Fungal populations are strongly influenced by the diversity and composition of the plant community and affect plant growth through mutualism, pathogenicity and their effect on nutrient 
availability and cycling [21, 22, 23]. Moreover, fungi participate in nitrogen fixation, hormone production, biological control against root pathogens and protection against drought $[24,25,26]$. They also play an essential role in stabilising soil organic matter and decomposing residues [27].

Fungi are an essential part of microbial ecology. Most fungi decompose the lignin and the hard-todigest soil organic matter, but some fungi consume simple sugars. Fungi dominate in low $\mathrm{pH}$ or slightly acidic soils where soils tend to be undisturbed. Fungi break down the organic residues so that many different microbes can start decomposing and process the residues into usable products. Approximately 80 to 90 percent of all plants form symbiotic mycorrhizae fungi relationships by creating hyphae networks. The hyphae are about $1 / 60$ the diameter of most plant root hairs and assist the plant in acquiring nitrogen, phosphorus, micronutrients and water in exchange for sugar produced by the plant. This mutually beneficial relationship is called a mycorrhizae network [28].

Fungi prefer slightly acidic conditions, low disturbance soils, perennial plants, internal nutrient sources directly from the plant, highly stable forms of organic residues with high carbon to nitrogen $(\mathrm{C}: \mathrm{N})$ values and slower recycling time. Bacteria dominate in highly disturbed ecosystems with fast nutrient recycling, low C:N values, prefer annual plants, and external nutrient additions outside the plant. Bacteria are single-celled organisms and need a film of water to survive, while fungi are multi-celled organisms that proliferate and in great lengths in the soil (feet or meters). This allows fungi to bridge gaps in the soil to transport nutrients relatively far distances back to the plants [29]

\section{MATERIALS AND METHODS}

Six soil samples were collected from different locations in the Department of Microbiology Botanical Garden ATBU. The six samples (10 g each) were separately collected from each area at a distance of 30 meters and 5-10 cm depth. Each piece was packaged into a sterile bottle using a hand trowel and labelled appropriately. The soil samples were brought to the Microbiology Research Laboratory, Department of Biological Sciences, Abubakar Tafawa Balewa University Bauchi.

Isolation of cellulose-degrading fungi from the soil sample was carried out using a serial dilution method. One was obtained by shaking vigorously. Then $1 \mathrm{ml}$ sample of the above dilution was aseptically transferred into $9 \mathrm{ml}$ sterile distilled water and then shaken vigorously, and $10^{-2}, 10^{-3}$ and $10^{-4}$ dilution was obtained. After that, $0.1 \mathrm{ml}$ of each dilution was pipetted out and spread into Berg's media containing $2 \mathrm{~g} \mathrm{NaNO}_{3}, 0.5 \mathrm{~g} \mathrm{MgSO}_{4}$, $0.005 \mathrm{~g} \mathrm{~K}_{2} \mathrm{HPO}_{4}, 0.01 \mathrm{~g} \mathrm{FeSO}_{4}, 0.02 \mathrm{~g} \mathrm{CaCl}_{2}, 0.002$ $\mathrm{g} \mathrm{MnSO}_{4}$ and $15 \mathrm{~g}$ agar supplemented with $5 \mathrm{~g}$ CMC in $1 \mathrm{l}$ of distilled water. The Medium was supplemented with streptomycin to inhibit bacterial growth. The inoculated plates were then incubated at $28{ }^{\circ} \mathrm{C}$ for 3-7 days. Sub-culture of isolated fungi was done based on their different morphologies on potato dextrose agar medium [30].

Carboxymethyl-cellulose (CMC) acts as a good indicator of cellulolytic ability. Isolated fungal isolates were screened by activity zone technique using Congo red dye. Congo red dye is a metachromatic dye that can react with cellulose. The CMC was stained red to deep pink. After the treatment of CMC with cellulase enzyme, the excess dye was washed gently with $\mathrm{NaCl}$, and it was observed for substrate utilisation zone around the colony. Unstained areas indicated where the CMC has broken down to $\beta-1$, four glucans that contained fewer glucose residues [31].

Isolated cellulolytic fungi were identified based on their cultural characteristics and the morphology of their sporulating structures. Using the light microscope, the morphology of the fungi was studied by staining with lactophenol cotton blue [31].

\section{RESULTS AND DISCUSSION}

All three sites presented a fungal diversity as six isolates were confirmed to be fungi (Table 1). The six isolates obtained were Penicillium chrysogenum, Emericella rogulosus, Aspergillus terreus, Aspergillus flavus, Aspergillus niger, Aspergillus fumigatus, all coded as BG1, BG2, BG3, BG4, BG5 and BG6, respectively.

Table 1 - Distribution of Fungal species according to Sample location

\begin{tabular}{|c|c|c|}
\hline $\begin{array}{c}\text { Isolate } \\
\text { source }\end{array}$ & $\begin{array}{c}\text { Number of } \\
\text { soil samples } \\
\text { collected } \\
(\mathrm{n}=6)\end{array}$ & $\begin{array}{c}\text { Fungal species isolated } \\
\text { (coded) }\end{array}$ \\
\hline BGA & 02 & $\begin{array}{l}\text { Aspergillus terreus, } \\
\text { Aspergillus flavus, }\end{array}$ \\
\hline
\end{tabular}




\begin{tabular}{|c|c|l|}
\hline $\begin{array}{c}\text { Isolate } \\
\text { source }\end{array}$ & $\begin{array}{c}\text { Number of } \\
\text { soil samples } \\
\text { collected } \\
(\mathrm{n}=6)\end{array}$ & \multicolumn{1}{|c|}{\begin{tabular}{c}
\multicolumn{1}{c|}{ Fungal species isolated } \\
(coded)
\end{tabular}} \\
\hline BGB & 02 & $\begin{array}{l}\text { Aspergillus niger, } \\
\text { Aspergillus fumigatus, } \\
\text { Emericella rogulosus, } \\
\text { Penicillium chrysogenum }\end{array}$ \\
\hline BGC & 02 & $\begin{array}{l}\text { Aspergillus terreus, } \\
\text { Aspergillus flavus, } \\
\text { Aspergillus niger, } \\
\text { Aspergillus fumigatus }\end{array}$ \\
\hline $\begin{array}{l}\text { Aspergillus terreus, } \\
\text { Aspergillus flavus, } \\
\text { Aspergillus niger, } \\
\text { Aspergillus fumigatus, } \\
\text { Emericella rogulosus, } \\
\text { Penicillium chrysogenum }\end{array}$ \\
\hline
\end{tabular}

Notes: BGA - Botanical Garden A; BGB - Botanical Garden B; BGC - Botanical Garden C

Among the isolates, BG5 (Aspergillus niger) was found to have the highest rate of occurrence (34.3\%), followed by $22.9 \%$ of BG3 (Aspergillus terreus) (Table 2).

Table 2 - Frequency of Fungal isolates from the various Soil samples

\begin{tabular}{|c|c|c|l|}
\hline $\begin{array}{c}\text { Isolates } \\
\text { code }\end{array}$ & $\begin{array}{c}\text { Frequency } \\
(\mathrm{n}=35)\end{array}$ & $\%$ & \multicolumn{1}{|c|}{$\begin{array}{c}\text { Fungal species } \\
\text { Isolated }\end{array}$} \\
\hline BG1 & 04 & 11.4 & $\begin{array}{l}\text { Penicillium } \\
\text { chrysogenum }\end{array}$ \\
\hline BG2 & 03 & 8.5 & $\begin{array}{l}\text { Emericella } \\
\text { rogulosus }\end{array}$ \\
\hline BG3 & 08 & 22.9 & Aspergillus terreus \\
\hline BG4 & 03 & 8.7 & Aspergillus flavus \\
\hline BG5 & 12 & 34.3 & Aspergillus niger \\
\hline BG6 & 05 & 14.3 & $\begin{array}{l}\text { Aspergillus } \\
\text { fumigatus }\end{array}$ \\
\hline
\end{tabular}

Notes: $\mathrm{n}$ - total number of occurrences; BG - Botanical Garden

This fungal diversity might be due to the richness in the organic matter content of the humic soil from decayed leaves in the Botanical Garden, which might favour the growth of different species of fungi. This agrees with the findings of [16], who reported a higher isolation rate $(50 \%)$ from organically-rich soil than from nutrient-deficient soil $(20 \%)$.

Fungal species are the essential sources of cellulase because of their high capability to hydrolyse cellulose and have been used frequently for enzyme production by solid-state fermentation [32].

Out of the six fungal isolates screened for cellulase production, BG5 from BGA had the highest zone of cellulose hydrolysis $(18 \mathrm{~mm})$ on carboxymethyl cellulose media (CMC), followed by BG3 $(15 \mathrm{~mm})$ also from the BGA. The rest of the isolates also showed considerate levels of cellulose hydrolysis, as shown in Table 3.

Table 3 - Cellulase Production by the various fungal Isolates

\begin{tabular}{|l|l|c|}
\hline $\begin{array}{c}\text { Isolates } \\
\text { code }\end{array}$ & Fungal Isolates & $\begin{array}{c}\text { Diameter of Zone of } \\
\text { Cellulose Hydrolysis } \\
\text { (mm) }\end{array}$ \\
\hline BG1 & $\begin{array}{l}\text { Penicillium } \\
\text { chrysogenum }\end{array}$ & 3.0 \\
\hline BG2 & $\begin{array}{l}\text { Emericella } \\
\text { rogulosus }\end{array}$ & 5.0 \\
\hline BG3 & $\begin{array}{l}\text { Aspergillus } \\
\text { terreus }\end{array}$ & 15.0 \\
\hline BG4 & $\begin{array}{l}\text { Aspergillus } \\
\text { flavus }\end{array}$ & 11.0 \\
\hline BG5 & Aspergillus niger & 18.0 \\
\hline BG6 & $\begin{array}{l}\text { Aspergillus } \\
\text { fumigatus }\end{array}$ & 9.0 \\
\hline
\end{tabular}

Notes: $\mathrm{BG}=$ Botanical Garden

\section{CONCLUSION}

The research has shown that fungi can be isolated from soil rich in humus and used for cellulase production. It was found that the genus Aspergillus have a high frequency of occurrence in the soil. The study also confirmed that fungi contribute immensely to cellulosic materials' biodegradation in the soil.

\section{Acknowledgement}

Our profound gratitude goes to our supervisors, microbiology lecturers and technologies for dedicating so much time and energy in guiding and instructing; to our colleagues who contributed in one way or the other toward the successful completion of this work.

\section{Conflict of Interests}

The authors declare no conflicting interest 


\section{REFERENCES}

1. Lynd, L. R., Weimer, P. J., van Zyl, W. H., \& Pretorius, I. S. (2002). Microbial Cellulose Utilization: Fundamentals and Biotechnology. Microbiology and Molecular Biology Reviews, 66(3), 506-577. doi: 10.1128/mmbr.66.3.506-577.2002

2. Zhu, Z., Sathitsuksanoh, N., \& Percival Zhang, Y.-H. (2009). Direct quantitative determination of adsorbed cellulase on lignocellulosic biomass with its application to study cellulase desorption for potential recycling. The Analyst, 134(11), 2267. doi: 10.1039/b906065k

3. Sukumaran, R. K., Singhania, R. R., \& Pandey, A. (2005). Microbial cellulases - production, applications and challenges. Journal of Science and Industrial Research, 64, 832-844.

4. Holker, U., Hofer, M., \& Lenz, J. (2004). Biotechnological advantages of laboratory-scale solid-state fermentation with fungi. Applied Microbiology and Biotechnology, 64(2), 175-186. doi: 10.1007/s00253-003-1504-3

5. Singhania, R. R., Patel, A. K., Soccol, C. R., \& Pandey, A. (2009). Recent advances in solid-state fermentation. Biochemical Engineering Journal, 44(1), 13-18. doi: 10.1016/j.bej.2008.10.019

6. Elisashvili, V., Kachlishvili, E., Tsiklauri, N., Metreveli, E., Khardziani, T., \& Agathos, S. N. (2008). Lignocellulose-degrading enzyme production by white-rot Basidiomycetes isolated from the forests of Georgia. World Journal of Microbiology and Biotechnology, 25(2), 331-339. doi: 10.1007/s11274-008-9897-x

7. Mathew, G. M., Sukumaran, R. K., Singhania, R. R., \& Ashok, P. (2008). Progress in research on fungal cellulases for lignocellulose degradation. Journal of Scientific and Industrial Research, 67(11), 898-907.

8. Coughlan, M. P., Moloney, A. P., McCrae, S. I., \& Wood, T. M. (1987). Cross-synergistic interactions between components of the cellulase systems of Talaromyces emersonii, Fusarium solani, Penicillium funiculosum and Trichoderma koningii. Biochemical Society Transactions, 15(2), 263-264. doi: 10.1042/bst0150263

9. Khandelwal, M., \& Windle, A. H. (2013). Hierarchical Organisation in the Most Abundant Biopolymer -Cellulose. MRS Proceedings, 1504. doi: 10.1557/opl.2013.379

10. Holtzapple, M. T. (2003). Cellulose. In B. Caballero, Encyclopedia of Food Sciences and Nutrition (2nd ed., pp. 998-107). Oxford: Academic Press.

11. Aravamudhan, A., Ramos, D. M., Nada, A. A., \& Kumbar, S. G. (2014). Natural Polymers. Natural and Synthetic Biomedical Polymers, 67-89. doi: 10.1016/b978-0-12-396983-5.00004-1

12. Rose, M., \& Palkovits, R. (2011). Cellulose-Based Sustainable Polymers: State of the Art and Future Trends. Macromolecular Rapid Communications, 32(17), 1299-1311. doi: 10.1002/marc.201100230

13. Aunina, Z., Bazbauers, G., \& Valters, K. (2010). Feasibility of Bioethanol Production From Lignocellulosic Biomass. Scientific Journal of Riga Technical University. Environmental and Climate Technologies, 4(-1), 11-15. doi: 10.2478/v10145-010-0011-x

14. Ingham, E. R. (2009). Soil Biology. Retrieved from https://www.nrcs.usda.gov/wps/portal/nrcs/main/soils/health/biology/

15. Sun, J.-M., Irzykowski, W., Jedryczka, M., \& Han, F.-X. (2005). Analysis of the Genetic Structure of Sclerotinia sclerotiorum (Lib.) de Bary Populations from Different Regions and Host Plants by Random Amplified Polymorphic DNA Markers. Journal of Integrative Plant Biology, 47(4), 385395. doi: 10.1111/j.1744-7909.2005.00077.x

16. Žifčáková, L., Větrovský, T., Howe, A., \& Baldrian, P. (2015). Microbial activity in forest soil reflects the changes in ecosystem properties between summer and winter. Environmental Microbiology, 18(1), 288-301. doi: 10.1111/1462-2920.13026 
17. Baldrian, P. (2003). Interactions of heavy metals with white-rot fungi. Enzyme and Microbial Technology, 32(1), 78-91. doi: 10.1016/s0141-0229(02)00245-4

18. López-Bucio, J., Pelagio-Flores, R., \& Herrera-Estrella, A. (2015). Trichoderma as biostimulant: exploiting the multilevel properties of a plant beneficial fungus. Scientia Horticulturae, 196, 109123. doi: $10.1016 /$ j.scienta.2015.08.043

19. Rouphael, Y., Franken, P., Schneider, C., Schwarz, D., Giovannetti, M., Agnolucci, M., ... Colla, G. (2015). Arbuscular mycorrhizal fungi act as biostimulants in horticultural crops. Scientia Horticulturae, 196, 91-108. doi: 10.1016/j.scienta.2015.09.002

20. Francis, F., Sabu, A., Nampoothiri, K. M., Ramachandran, S., Ghosh, S., Szakacs, G., \& Pandey, A. (2003). Use of response surface methodology for optimising process parameters for the production of $\alpha$-amylase by Aspergillus oryzae. Biochemical Engineering Journal, 15(2), 107-115. doi: 10.1016/s1369-703x(02)00192-4

21. Wardle, D. A. (2002). Communities and Ecosystems: Linking Aboveground and Belowground Components. Princeton: Princeton University Press.

22. Wagg, C., Bender, S. F., Widmer, F., \& van der Heijden, M. G. A. (2014). Soil biodiversity and soil community composition determine ecosystem multifunctionality. Proceedings of the National Academy of Sciences, 111(14), 5266-5270. doi: 10.1073/pnas.1320054111

23. Hannula, S. E., Morriën, E., de Hollander, M., van der Putten, W. H., van Veen, J. A., \& de Boer, W. (2017). Shifts in rhizosphere fungal community during secondary succession following abandonment from agriculture. The ISME Journal, 11(10), 2294-2304. doi: 10.1038/ismej.2017.90

24. Jayne, B., \& Quigley, M. (2013). Influence of arbuscular mycorrhiza on growth and reproductive response of plants under water deficit: a meta-analysis. Mycorrhiza, 24(2), 109-119. doi: 10.1007/s00572-013-0515-x

25. Baum, C., El-Tohamy, W., \& Gruda, N. (2015). Increasing the productivity and product quality of vegetable crops using arbuscular mycorrhizal fungi: A review. Scientia Horticulturae, 187, 131141. doi: $10.1016 /$ j.scienta.2015.03.002

26. El Komy, M. H., Saleh, A. A., Eranthodi, A., \& Molan, Y. Y. (2015). Characterisation of Novel Trichoderma asperellum Isolates to Select Effective Biocontrol Agents Against Tomato Fusarium Wilt. The Plant Pathology Journal, 31(1), 50-60. doi: 10.5423/ppj.oa.09.2014.0087

27. Treseder, K. K., \& Lennon, J. T. (2015). Fungal Traits That Drive Ecosystem Dynamics on Land. Microbiology and Molecular Biology Reviews, 79(2), 243-262. doi: 10.1128/mmbr.00001-15

28. Magdoff, F., \& Van Es, H. (2009). Building Soils for Better Crops (4th ed.). Retrieved from https://www.sare.org/wp-content/uploads/Building-Soils-for-Better-Crops.pdf

29. Lowenfels, J., \& Lewis, W. (2010). Teaming with Microbes. Portland: Timber Press.

30. Sivakumaran, S. (2014). Isolation of cellullolytic fungi and their degredation on cellulosic agricultural wastes. Journal of Academia and Industrial Research, 2(8), 458-463.

31. Reddy, P. L., Babu, B.., Radhaiah, A., \& Sreeramulu, A. (2014). Screening, Identification and isolation of cellulolytic fungi from soils of Chittoor district, India. International Journal of current Microbiology and Applied Sciences, 3(7), 761-771.

32. Mrudula, S., \& Murugammal, R. (2011). Production of cellulose by Aspergillus niger under submerged and solid state fermentation using coir waste as a substrate. Brazilian journal of microbiology : [publication of the Brazilian Society for Microbiology], 42(3), 1119-1127. 